\section{Pepper Transplants Are Excessively Damaged by Brushing}

\author{
Joyce G. Latimer ${ }^{1}$ \\ Department of Horticulture, Georgia Experiment Station, University of Georgia, \\ Griffin, GA 30223-1797
}

Additional index words. Capsicum annuum, mechanical conditioning, growth regulation, shade level, stress

\begin{abstract}
Jupiter' or 'Marengo' pepper (Capsicum annuum L.) seedlings maintained under $0 \%, 30 \%, 50 \%$, or $80 \%$ shade in a greenhouse were brushed 80 strokes twice daily beginning at the cotyledonary, first true leaf, or second true leaf stage. Averaged across shade environments, brushing reduced 'Jupiter' and 'Marengo' stem length $25 \%$ to $36 \%$ and $6 \%$ to $28 \%$, respectively. However, the percentage of plants exhibiting mechanical damage by brushing ranged from $86 \%$ to $93 \%$ and $48 \%$ to $90 \%$ for 'Jupiter' and 'Marengo', respectively. Transplant quality tended to decrease as brushing was delayed. When brushing of 'Marengo' was reduced to 40 strokes twice daily in 1992, plant growth reduction decreased, but the percent damage was about the same. The damage severity, however, was reduced as indicated by higher plant-quality ratings. Pepper plant damage was excessive for the small amount of growth regulation provided by brushing.
\end{abstract}

Mechanical conditioning (intentional mechanical stress applied to affect plant growth) is an effective and generally nondamaging height and quality control method for various vegetable transplants in the Solanaceae, Cucurbitaceae, and Cruciferae families (Latimer, 1991). Many factors affecting plant response to mechanical stress are unknown. Tomato (Lycopersicon esculentum Mill.) growth was reduced more by shaking during the winter than shaking during the summer when shadecloth was used to provide conditions of equivalent total solar energy (Heuchert and Mitchell, 1983). Differential plant shading in the greenhouse during the summer resulted in greater reductions in stem elongation in response to shaking under low (17\% full sun) light levels (Heuchert and Mitchell, 1983). Pappas and Mitchell (1985) reported a similar response with soybean [Glycine $\max (\mathrm{L}$.) Merr.].

Mechanical conditioning by brushing caused slight leaf damage to 'Marengo' pepper transplants during a summer study but resulted in excessive plant damage in subsequent spring studies, suggesting that the lower light levels prevalent in early spring exacerbated brushing damage (Latimer, 1992). My objectives were to examine the effect of brushing on growth and damage of bell pepper plants under various shade levels during the summer.

\section{Materials and Methods}

In July 1991, four shading environments were established in a nonshaded greenhouse. Sections of shadecloth providing $30 \%, 50 \%$,

Received for publication 16 Dec. 1993. Accepted for publication 19 Apr. 1994. The cost of publishing this paper was defrayed in part by the payment of page charges. Under postal regulations, this paper therefore must be hereby marked advertisement solely to indicate this fact.

${ }^{1}$ Associate Professor. or $80 \%$ shade were draped over 1.5 -m-long $\times$ 1 -m-wide $\times 1$-m-high frames attached to the benches. Eight flats of plants were placed in each shade environment. The flats were randomized within each shade environment weekly to minimize position effects. An uncovered area represented $0 \%$ shade. Actual photosynthetic photon flux (PPF) levels at noon under the $30 \%, 50 \%$, and $80 \%$ shade treatments were $53 \%, 42 \%$, and $23 \%$, respectively, of that measured with $0 \%$ shade. 'Jupiter' and 'Marengo' bell pepper seeds were sown directly into cell-packs (cell dimensions $3.8 \times 3.8 \times 6.0 \mathrm{~cm}, 48 \mathrm{~cm}^{3}$ ) (Kord Products, Brampton, Canada) filled with a peatlite medium (Redi-Earth; Grace-Sierra Horticultural Products, Cambridge, Mass.). To promote uniform germination, all flats were held in the $50 \%$ shade area for 10 days after seeding (DAS). Then, the plants were thinned to one per cell, and 24 plants (four cell-packs) were assigned to each treatment with three replications and moved into the various shade environments. Plants were brushed 80 strokes (back and forth across the flat 40 times) twice daily with a wooden pole that was moved by hand on a track attached to the bench (Baden and Latimer, 1992). Brushing started as the plants attained various leaf developmental stages. Brushing at the cotyledonary, first true leaf (area $\approx 2 \mathrm{~cm}^{2}$ ), and second true leaf stages were initiated 13, 15, and 17 DAS, respectively. Maximum and minimum temperatures within the shade environments did not vary significantly. Greenhouse air averaged 30/22C (day/ night) and the PPF under the $50 \%$ shade averaged $8.9 \mathrm{~mol} \cdot \mathrm{m}^{-2} \cdot$ day $^{-1}$. Plants were fertilized with $200 \mathrm{ppm} \mathrm{N}$ through $20 \mathrm{~N}-8.7 \mathrm{P}-16.6 \mathrm{~K}$ (Peter's 20-20-20; W.R. Grace \& Co., Cambridge, Mass.) twice weekly beginning 10 DAS.

Brushing continued until control plants reached transplant size $(\approx 20 \mathrm{~cm}$ high). Because 'Marengo' was more vigorous, its plants were harvested at 35 DAS; 'Jupiter' plants were harvested at 42 DAS. Each cell-pack (six plants) was evaluated for ratings and damage counts. The plants in each cell-pack were assigned an average subjective quality rating using a continuous 0 to 100 scale $(0=$ poor, $100=$ excellent $)($ Heintz and Kader, 1983). In my assessment, plants rated 70 or higher were considered marketable as bedding plants. The number of plants in each cell-pack exhibiting any visible mechanical damage as a result of brushing (e.g., torn leaves, broken leaves or stems, or new growth deformation) and the types of damage observed were noted. Damage counts were expressed as the percentage of plants damaged. Six plants were randomly selected from each treatment in each of three replications for stem length and shoot dryweight measurements (after $72 \mathrm{~h}$ in a $70 \mathrm{C}$ forced-air oven).

The same study was repeated in July 1992 with 'Marengo' and new shadecloth reported to provide $30 \%, 51 \%$, or $80 \%$ shade (actual noon PPF levels were $59 \%, 33 \%$, or $10 \%$ that of the unshaded treatment). In an attempt to reduce plant damage, brushing was reduced to 40 strokes twice daily and was initiated 12 DAS at the cotyledonary, 16 DAS at the first true leaf, and 20 DAS at the second true leaf stage. Plants were rated and harvested at 37 DAS as previously described. Greenhouse air averaged 30/21C (day/night) with an average PPF of $10.3 \mathrm{~mol} \cdot \mathrm{m}^{-2} \cdot$ day $^{-1}$ under $51 \%$ shade.

In both years, the design was a split plot, with brushing treatments randomized within shade main plots, with three replications. Percentage data were subjected to arcsin transformation for analysis and mean separation; raw data are presented. All data were subjected to SAS general linear models procedure (Littell et al., 1991).

\section{Results and Discussion}

Due to significant interactions between shade and brushing for most measurements, all data are presented by shade environment. Because the percentage of plants damaged by brushing was so high, regardless of when brushing started, the data for all brushing treatments were pooled and compared to nonbrushed plants using a single-degree-offreedom contrast at $P \leq 0.05$. Only the pooled data are presented. Time of brushing initiation had few significant effects on plant growth, but later initiation generally reduced the quality ratings of the transplants in all shade environments (data not presented).

'Jupiter' stem length was reduced $25 \%$ to $36 \%$ by brushing, but shoot dry weight was reduced $10 \%$ to $28 \%$ when averaged over the shade environments in 1991 (Table 1). The number of plants injured by brushing did not differ with the developmental stage at which brushing started under any of the shade environments (data not presented). Brushed 'Jupiter' transplants had torn and broken leaves, distorted new growth, and broken stems. As a result, the brushed plant quality ratings were low, and I would not consider the plants to be marketable. The types of damage noted would not reduce plant viability per se, but in previ- 
ous tests, the damage did reduce subsequent transplant growth and drought tolerance (J.G.L., unpublished).

In 1991, 'Marengo' stem length was only shade, but brushing resulted in $28 \%$ reductions in stem growth in $30 \%$ or $50 \%$ shade (Table 1). Brushing reduced 'Marengo' shoot dry weight in only $30 \%$ and $50 \%$ shade. Brushing increased shoot dry weight of plants in $0 \%$ shade and had no effect on those grown in $80 \%$ shade. The percentage of plants damaged by brushing was less in the $0 \%$ and $30 \%$ shade environments than in $50 \%$ and $80 \%$ shade, but slightly reduced by brushing in $0 \%$ and $80 \%$

there were no differences in percent damage with respect to time of brushing initiation in any of the shade environments (data not presented). Torn or broken leaves, distorted new growth, and occasional broken stems were the types of damage noted. Brushing also reduced the transplant quality rating.

Results of the 1992 study with 'Marengo' were similar to those presented for 1991, except that the fewer passes ( 40 strokes) resulted in less stem length reduction (Table 2 ), which ranged from $7 \%$ to $18 \%$ vs. $6 \%$ to $28 \%$ in 1991. Treatment $\times$ shade interactions were significant for all plant measurements. Shoot

Table 1. Effect of shade environment and brushing (data pooled for brushing initiated at the cotyledonary, first true leaf, or second true leaf stage) on growth, percentage of plants exhibiting mechanical damage, and a quality rating (continuous 0 to 100 scale, where $0=$ poor and $100=$ excellent) of 'Jupiter' and 'Marengo' peppers brushed 80 strokes twice daily in 1991.

\begin{tabular}{|c|c|c|c|c|c|c|c|c|}
\hline \multirow[b]{3}{*}{ Treatment } & \multicolumn{8}{|c|}{ Cultivar } \\
\hline & \multicolumn{4}{|c|}{ Jupiter } & \multicolumn{4}{|c|}{ Marengo } \\
\hline & $\begin{array}{l}\text { Stem } \\
\text { length } \\
(\mathrm{mm})\end{array}$ & $\begin{array}{l}\text { Shoot } \\
\text { dry wt } \\
(\mathrm{mg})\end{array}$ & $\begin{array}{c}\text { Plants } \\
\text { damaged } \\
(\%)^{\mathrm{z}}\end{array}$ & $\begin{array}{l}\text { Quality } \\
\text { rating }\end{array}$ & $\begin{array}{l}\text { Stem } \\
\text { length } \\
(\mathrm{mm})\end{array}$ & $\begin{array}{l}\text { Shoot } \\
\text { dry wt } \\
(\mathrm{mg})\end{array}$ & $\begin{array}{c}\text { Plants } \\
\text { damaged } \\
(\%)^{\mathrm{z}}\end{array}$ & $\begin{array}{c}\text { Quality } \\
\text { rating }\end{array}$ \\
\hline \multicolumn{9}{|l|}{$0 \%$ Shade } \\
\hline Control & 190 & 392 & 0 & 91 & 153 & 276 & 0 & 86 \\
\hline Brushed & 137 & 351 & 86 & 55 & 143 & 335 & 57 & 65 \\
\hline Contrast & $* * *$ & $* *$ & $* * *$ & $* * *$ & $* * *$ & $* * *$ & $* * *$ & $* * *$ \\
\hline \multicolumn{9}{|l|}{$30 \%$ Shade } \\
\hline Control & 187 & 363 & 0 & 90 & 202 & 362 & 0 & 85 \\
\hline Brushed & 127 & 285 & 89 & 49 & 145 & 289 & 48 & 48 \\
\hline Contrast & $* * *$ & $* * *$ & $* * *$ & $* * *$ & $* * *$ & $* * *$ & $* * *$ & $* * *$ \\
\hline \multicolumn{9}{|l|}{$50 \%$ Shade } \\
\hline Control & 204 & 373 & 0 & 85 & 204 & 368 & 0 & 75 \\
\hline Brushed & 130 & 270 & 90 & 46 & 146 & 278 & 90 & 41 \\
\hline Contrast & $* * *$ & $* * *$ & $* * *$ & $* * *$ & $* * *$ & $* * *$ & $* * *$ & $* * *$ \\
\hline \multicolumn{9}{|l|}{$80 \%$ Shade } \\
\hline Control & 181 & 362 & 0 & 77 & 173 & 286 & 0 & 70 \\
\hline Brushed & 135 & 270 & 93 & 47 & 160 & 262 & 90 & 45 \\
\hline Contrast & $* * *$ & $* * *$ & $* *$ & $* * *$ & $*$ & NS & $* * *$ & $* * *$ \\
\hline \multicolumn{9}{|l|}{ Shade $\times$} \\
\hline treatment & $* * *$ & NS & NS & $* * *$ & $* * *$ & $* * *$ & $* *$ & $* * *$ \\
\hline
\end{tabular}

${ }^{2}$ Percentages subjected to arcsin transformation for analysis; raw data are presented.

ss, *,**,*** Nonsignificant or significant at $P \leq 0.05,0.01$, or 0.001 , respectively; single-degree-of-freedom contrasts of control vs. brushed (three treatments pooled).

Table 2. Effect of shade environment and brushing (data pooled for brushing initiated at the cotyledonary, first true leaf, or second true leaf stage) on growth, percentage of plants exhibiting mechanical damage, and a quality rating (continuous 0 to 100 scale, where $0=$ poor to $100=$ excellent) of 'Marengo' peppers brushed 40 strokes twice daily in 1992.

\begin{tabular}{|c|c|c|c|c|}
\hline Treatment & $\begin{array}{c}\text { Stem } \\
\text { length } \\
(\mathrm{mm})\end{array}$ & $\begin{array}{c}\text { Shoot } \\
\text { dry wt } \\
(\mathrm{mg})\end{array}$ & $\begin{array}{c}\text { Plants } \\
\text { damaged }^{\mathrm{z}} \\
(\%)\end{array}$ & $\begin{array}{l}\text { Quality } \\
\text { rating }\end{array}$ \\
\hline \multicolumn{5}{|l|}{$0 \%$ Shade } \\
\hline Control & 212 & 805 & 0 & 95 \\
\hline Brushed & 179 & 608 & 47 & 92 \\
\hline Contrast & $* * *$ & $* * *$ & $* * *$ & $* * *$ \\
\hline \multicolumn{5}{|l|}{$30 \%$ Shade } \\
\hline Control & 225 & 685 & 0 & 96 \\
\hline Brushed & 185 & 616 & 77 & 84 \\
\hline Contrast & $* * *$ & NS & $* * *$ & $* * *$ \\
\hline \multicolumn{5}{|l|}{$51 \%$ Shade } \\
\hline Contol & 206 & 628 & 0 & 91 \\
\hline Brushed & 192 & 509 & 71 & 80 \\
\hline Contrast & $* * *$ & $* * *$ & $* * *$ & $* * *$ \\
\hline \multicolumn{5}{|l|}{$80 \%$ Shade } \\
\hline Contol & 178 & 376 & 0 & 78 \\
\hline Brushed & 157 & 332 & 65 & 74 \\
\hline Contrast & $* * *$ & $*$ & $* * *$ & $* * *$ \\
\hline Shade $\times$ treatment & $* * *$ & $*$ & $* * *$ & $* * *$ \\
\hline
\end{tabular}

${ }^{2}$ Percentages subjected to arcsin transformation for analysis; raw data are presented.

NS, ${ }^{*}, * * *$ Nonsignificant or significant at $P \leq 0.05$ or 0.001 , respectively; single-degree-of-freedom contrasts of control vs. brushed (three treatments pooled). dry weight decreased due to brushing in each shade density, except $30 \%$. Overall, using fewer brushing strokes in 1992 did not reduce the percentage of plants damaged by treatments much; damage averaged $47 \%$ to $77 \%$. However, the amount of plant damage was less with the less intense brushing treatment, where the primary damage was torn leaves with few broken leaves and no broken stems. This difference resulted in higher quality ratings in 1992 than in 1991. For example, the average quality rating for brushed plants in the 0\% shade plot in 1992 was 92 compared to 65 in 1991. Quality ratings of the brushed plants were $\geq 89$ in $0 \%$ shade in 1992 and were $>70$ in the other shade environments (Table 2).

Pepper is not a crop suited to growth regulation by brushing due to the extensive injury inflicted by the treatment for even moderate regulation of stem elongation. Shading (i.e., reduced light quantity) tended to increase damage from brushing, as suggested by previous studies performed in the spring (Latimer, 1992). Shading decreases leaf thickness (Bunce et al., 1977), which tends to make leaves more fragile. However, the amount of damage incurred by brushed transplants in $0 \%$ shade in these studies would be unacceptable for most markets.

Pepper leaves and stems are more brittle than those of tomato. Brittle plant tissues or plants with more upright growth habits have exhibited greater damage with brushing than more elastic tissues or plants with more lateral growth (Latimer, 1991). Also, the waxy nature of pepper leaves presumably increases the friction between the leaves and the brushing bar, which results in leaf tearing. The exposed position of pepper's apical meristem makes it more susceptible to damage than tomato, for example. Noncontact methods of mechanical conditioning, such as shaking, may provide growth regulation without the excessive damage seen in these studies.

\section{Literature Cited}

Baden, S.A. and J.G. Latimer. 1992. An effective system for brushing vegetable transplants for height control. HortTechnology 2:412-414.

Bunce, J.A., D.T. Patterson, M.M. Peet, and R.S. Alberte. 1977. Light acclimation during and after leaf expansion in soybean. Plant Physiol. 60:255-258

Heintz, C.M. and A.A. Kader. 1983. Procedures for the sensory evaluation of horticultural crops. HortScience 18:18-22.

Heuchert, J.C. and C.A. Mitchell. 1983. Inhibition of shoot growth in greenhouse-grown tomato by periodic gyratory shaking. J. Amer. Soc. Hort. Sci. 108:795-801.

Latimer, J.G. 1991. Mechanical conditioning for control of growth and quality of vegetable transplants. HortScience 26:1456-1461.

Latimer, J.G. 1992. For height control, give transplants the brush. Amer. Veg. Grower 40(4):62, $65,68,69$.

Littell, R.C., F.J. Freund, and P.C. Spector. 1991. SAS system for linear models. SAS Inst., Cary, N.C.

Pappas, T. and C.A. Mitchell. 1985. Effects of seismic stress on the vegetative growth of Glycine $\max$ (L.) Merr. cv. Wells II. Plant Cell \& Environ. 8:143-148. 